\title{
データベースの供用下溶接エキスパートシステ ムへの応用*
}

\author{
中西 保正 ${ }^{* *}$, 井本 泉***, 鈴木 博之****
}

\section{Application of Data Base to Expertsystem of in-service welding}

by Yasumasa Nakanishi**, Izumi Imoto*** and Hiroyuki Suzuki****

キーワード：データベース，エキスパートシステム，供用下溶接，補修 溶接, 維持管理, 橋梁

\section{1.はじめに}

情報の発達に伴い，各種分野でデータベースの利用が 増加している．溶接は旧くて新しい技術であり，精力的 に新技術の研究開発が行われている反面，成熟した技術 も多い，とくに，近年は人材と研究開発費が新技術分野 へ重点配分されることが多い。そのため, 成熟技術のポ テンシャル維持, 継承及び開発効率の向上が望まれ,デー タベースの活用が各分野で始められた。また，新たに開 発した技術を適用する場合に，刘応できる技術者が十分 でないことがよくあるが，エキスパートシステムは有効 な手段である。したがって，ここでは，橋梁の補修・補 強及び改造工事に端を発した「交通供用下における溶接 エキスパートシステム」の構築を通じて, データベース の応用例について紹介する。

近年, 交通量が予想外に増大し，車両重量の増加とあ いまって橋梁や高架橋の補修, 補強工事が行われてい る1)どほか, 交通渋滞の解消や車両重量增加への対応の

\footnotetext{
*原稿受付 平成 3 年 5 月 16 日

**会 員 石川島播嚰重工業侏 Member Ishikawajima Harima Heavity Industries, Co., Ltd.

***会 員 石川島播磨重工業侏 Member Ishikawajima Harima Heavity Industries, Co., Ltd.

****会 員 大阪大学 Member Osaka University
}

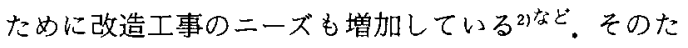
め, 車両の通行を止めないで施工を行う「供用下の溶接 技術」が望まれていたが，従来は経験的に供用下の溶接 を避ける方向であった。筆者らは近年の研究成果により

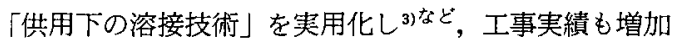
している，そこで，增加する工事のニーズとそれに対応 できる技術者の不足を補うため，これまでの研究成果及 び専門家の知識を集約し, 溶接の可否及び施工条件を選 定するエキスパートシステムを構筑した4).

\section{2. 供用下の浴接}

供用下の橋梁には自重による静的荷重が負荷されてい るほか, 車両が走行すると変動荷重による振動が生じ, さらにルートギャップが相対的に変位変動している，図 1 に実橋における振動, 変位変動の例を示す5).

静的荷重下の溶接では, 局部的に温度が上昇するため

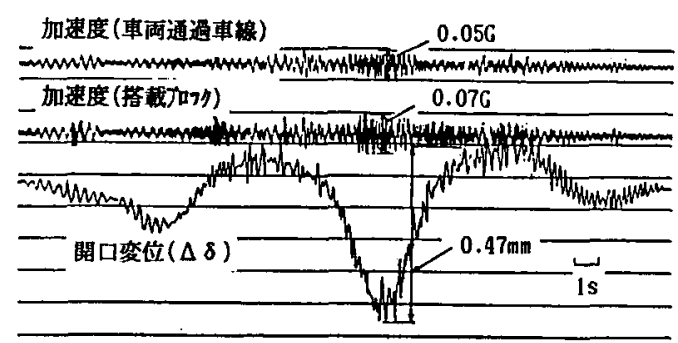

図 1 供用下の橋梁における振動と変位の例 
耐荷力が低下し，座届を含む過大な変形が生じたり溶接 割れに至る場合があるが，防止策が既に確立されてい る6).また，振動により溶接欠宿が生じることがあるほ か7), とくに変位変動下の溶接ては凝固・冷却中の溶接金 属に変動ひずみが作用し，工場溶接や無負荷状態の現地 溶接では問題とならなかった高温割れが発生したことが ある8).

そこで，変動荷重を負荷し，ルートギャップが変動し ている状態で試験溶接を行う「変動荷重下の割れ試験」 を実施した，高温割れの発生には変動成分のみが奇与す るため, 変動荷重下でも溶接割れが生じない条件（割れ 発生限界変位, 継手剛性及び周波数との関係, 各種溶接 棒の割れ発生限界值など)を見い出し9),10), 市販溶接棒と 比較して変動荷重下の耐高温割れ性が優れた溶接捧も開 発した ${ }^{11}$.

一方, 実施工に際しては，予め現地で振動及び変位変 動計測を行い，その結果をデータと参照して溶接の可否 及び溶接条件を選定する，また，高張力綱も使用されて いるほか, 古い橋梁では低温割れ感受性が高い鋼材も多 い.そのため, 適正な予熱条件を選定し, 低温割れを防 止することも必要となる。ささに，このような鋼材は $\mathrm{P}$, S，Cなどの高温割れが生じやすい元素を多く含有する ことも多く ${ }^{12)}$, 施工に際しては注意を要する.

\section{3. 供用下溶接エキスバートシステム}

供用下溶接エキスパートシステムのフローチャートを 図 2 に, 判定例を図 3 に示す.システムの環境はラップ トップパソコンやブックコンピューターでも作動する市 販エキスパートシェル上であり, 現地で計測した振動及 び変位変動值とその周波数, 綱種, 継手の種類などを入 力することにより, 使用溶接棒の選定, 予熱条件, 振動 に対する判定, 変位変動に対する判定, 入熱値などが即 座に得られる. 判定基準はこれまでの研究成果, 社内基 準及び公表された資料をデータベース化し，知識ベース に組み込んだ，次項にその内容を紹介する。

\section{4. データベースの組込みと判定方法}

\section{1 溶接棒の選定}

溶接棒の選定には使用鋼材の規格と溶接棒との対照表 を作成し，知識ベースにファクトとして記述した。また， 古い橋梁では無規格材や外国規格の鋼材もあるため, 強 度レベルを入力して溶接棒を選定できるようにした。

\section{2 予热条件の選定}

通常, 予熱条件は鋼材の化学組成, 溶接棒の水素量及 び継手の拘束度から求める。予熱条件の選定には多くの

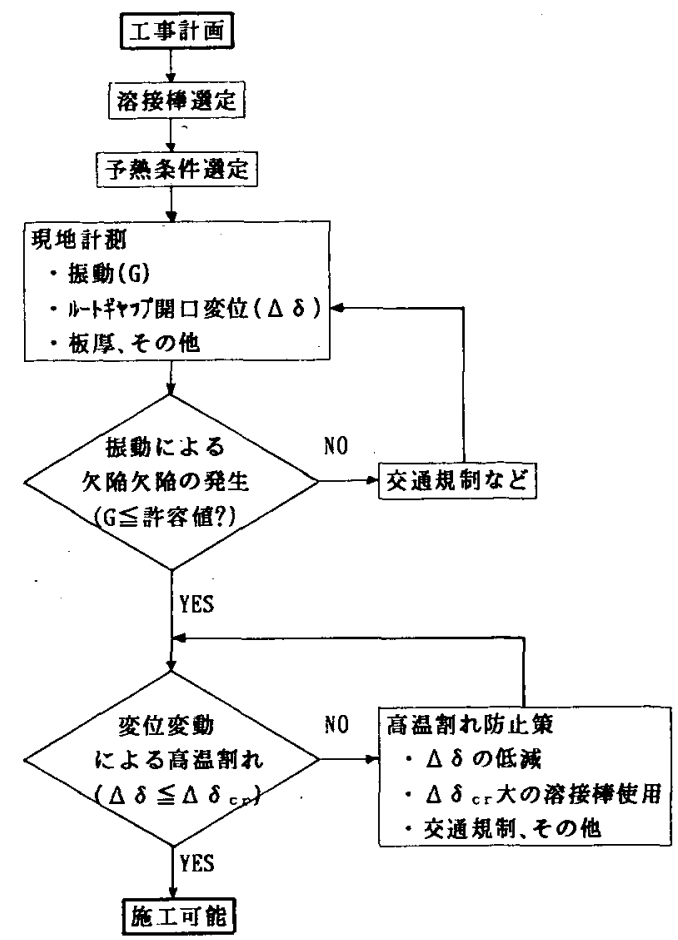

図 2 供用下溶接エキスパートシステムフロー チャート

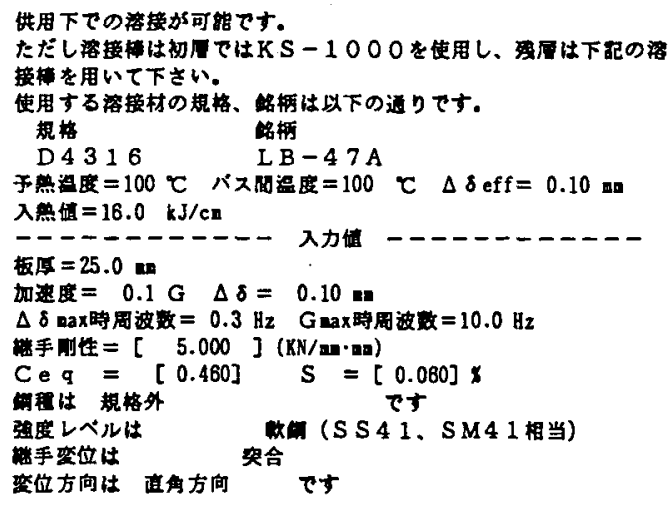

图 3 供用下溶接エキスパートシステムによる溶接 可否判定及び施工条件選定結果の例

方法があるが，近年は $\mathrm{P}_{\mathrm{CM}}$ (溶接割れ感受性組成)，水素

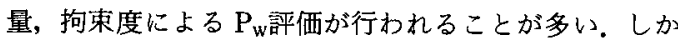
し, 橋梁に多く使用されている軟綱〜非調質型高張力綱 に対しては $\mathrm{P}_{C_{M}}$ よりも炭索当量 (Ceq)による評価の方が 合う13)ため，Ceq(JI) 式及び板厚と予熱温度 $(\mathrm{T})$ ，パス間 温度 $(\theta)$ との対照表を作成し，知識ベースにファクトと して記述した。表 1 に対照表の例を示す．T及び $\theta$ の値 は社内基準及び道路橋示方書に拘束度を含めた実績を加 昧して設定した，溶接棒は低水素系溶接棒を使用する。 
表 1 供用下溶接エキスパートシステムに括ける子 熱条件選定表

\begin{tabular}{|l|l|l|}
\hline \multirow{2}{*}{ Ceq (\%) } & \multicolumn{2}{|c|}{ 板厚 $\mathrm{t}(\mathrm{au})$} \\
\cline { 2 - 3 } & $\mathrm{t}<25$ & $25 \leq \mathrm{t}<50$ \\
\hline Ceq $\leq 0.35$ & $\mathrm{~T}=\theta=0$ & $\mathrm{~T}=\theta=0$ \\
\hline $0.35<\mathrm{Ceq} \leq 0.45$ & $\mathrm{~T}=0, \theta=75$ & $\mathrm{~T}=\theta=75$ \\
\hline $0.45<\mathrm{Ceq} \leq 0.50$ & $\mathrm{~T}=\theta=75$ & $\mathrm{~T}=\theta=100$ \\
\hline $0.50<\mathrm{Ceq}$ & $\mathrm{T}=\theta=100$ & $\mathrm{~T}=\theta=125$ \\
\hline
\end{tabular}

(注) $\mathrm{T}$ ：尒热温度 $\left(^{\circ} \mathrm{C}\right)$ $\theta:$ :

また，専門家以外でも判断ができるように，規格材に 対して綱種及び板厚と予熱温度 $(\mathrm{T})$, パス間温度 $(\theta)$ と の対照表も用意し, ファクトとして知識ベースに記述し た.

\section{3 振勒による久陷防止}

溶接部に振動が生じてもルートギャップに相対変位が 生じない場合には溶接割れは生じない24が，溶接欠陥が 生じるおそれがある7. そのため, 溶接部の振動が限界值 を越える場合はベントの設置や車線規制を行う必要があ る. 振動と欠陥発生との関係は既に求められており れらデータに試験及び工事実績を加味して図 4 に例を示 す許容振動量（加速度）の評価曲線を設定し, 周波数の 関数として知識ベースに組み迂んだ.

\section{4 変动荷重下の高温割れ防止}

図 5 に割れ発生限界ルートギャップ開口変位 $\left(\Delta \delta_{\mathrm{cr}}\right)$ と 溶接可否判定結果の例を示す，図中には夷際の工事にお けるルートギャップ開口変位 $(\Delta \delta)$ も示した. $\Delta \delta>\Delta \delta_{\mathrm{cr}}$ の場合には高温割れが発生するおそれがあるため, 拘束 材の設置や交通規則を奏施して $\Delta \delta$ を低減するか， $\Delta \delta_{\mathrm{cr}}$ が大きな溶接棒を使用する必要がある。

$\Delta \delta_{\mathrm{cr}}$ は溶接棒の化学組成, 継手剛性及び変位変動の周 波数に依存する。そのため，化学組成が異なる各種溶接 棒に対し，周波数及び継手剛性（面内拘束度）を変えて $\Delta \delta_{\mathrm{cr}}$ 求めた。図 5 は, 連続析橋の代表的な変位変動周波

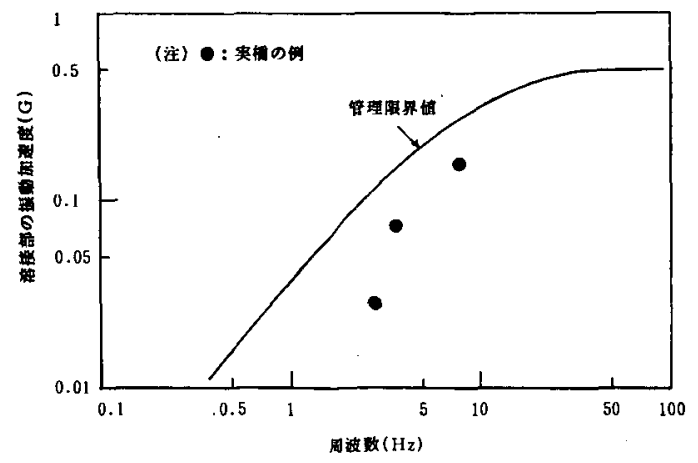

图4供用下溶接エキスパートシステムにおける振 動許容值（管理限界值）の例

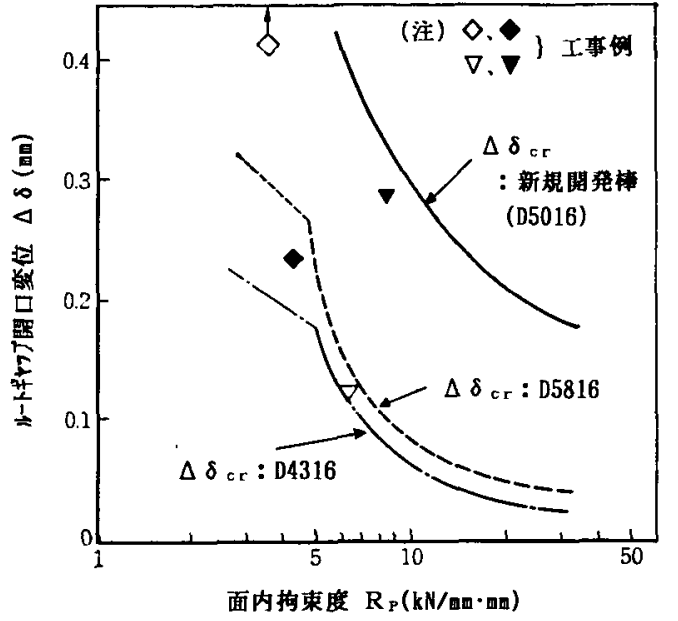

图 5 供用下の溶接における割れ発生限界ルート ギャップ開口変位 $\left(\Delta \delta_{\mathrm{cr}}\right)$ と溶接可否判定結果 (入熱: $22 \mathrm{~kJ} / \mathrm{cm}$, 周波数：0.33 Hz)

表 2 供用下溶接エキスパートシステムにおける ルートギャップ開口変位 $(\Delta \delta)$ 補正表

\begin{tabular}{|c|c|c|c|}
\hline \multicolumn{2}{|c|}{ 綶手 } & 変位方向 & $\Delta \delta_{\text {eff }}$ \\
\hline \multicolumn{2}{|c|}{ 荷重非伝達极肉粠手 } & - & 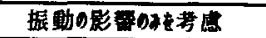 \\
\hline \multirow{2}{*}{$\begin{array}{l}\text { 荷重伝達 } \\
\text { 极肉手 }\end{array}$} & \multirow{2}{*}{ 開先好 } & 直角 & $\Delta \delta_{\text {off }}=0.8 \times \Delta \delta_{\max }$ \\
\hline & & th力野 & $\Delta \delta_{\text {of } f}=0.67 \times \Delta \delta_{\max }$ \\
\hline \multirow{2}{*}{ " } & \multirow{2}{*}{ 開先付 है } & 直角 & $\Delta \delta_{\text {eff }}=\Delta \delta_{\text {max }}$ \\
\hline & & thl暗 & $\Delta \delta_{\text {eff }}=0.67 \times \Delta \delta_{\text {max }}$ \\
\hline \multirow{2}{*}{\multicolumn{2}{|c|}{ 突合䋖手 }} & 直角 & $\Delta \delta_{\text {aff }}=\Delta \delta_{\text {max }}$ \\
\hline & & 世畹 & $\Delta \delta_{\text {eff }}=0.67 \times \Delta \delta_{\max }$ \\
\hline
\end{tabular}

(注) $\Delta \delta_{\text {eff }}: \Delta \delta$ o補正值

$\Delta \delta_{\text {LAX }}:$ 就既しk $\Delta \delta$ 最大值

数 $(0.33 \mathrm{~Hz})$ におてて継手剛性 (面内拘束度) で整理し た各種溶接棒に対する判定図 $\left(\Delta \delta_{\mathrm{cr}}\right)$ である。

実施工に際しては，現地で $\Delta \delta$ 及びその周波数を計測 し,該当する周波数における判定図を用いて継手剛性(面 内拘束度) から 4.1 項で求めた溶接棒の $\Delta \delta_{\mathrm{cr}}$ を求め, $\Delta \delta$ と比較する，しかし，該当する周波数のデータがない場 合には前後のデータから類推する必要があったため, 知 識ベースの構築に際しては継手剛性, 周波数, $\Delta \delta$ の関数 として定式化した ${ }^{15)}$. (1) 式に, 市販 JIS D 4316 溶接棒 のなかで割れ感受性が高い成分を有する溶接榛の凝固割 れ発生評価式の例を示す (左辺>1のときに割れ発生).

$\left\{\left(39.384 \times \log R_{P}-22.957\right)+\left(-0.481 \times \log R_{P}+\right.\right.$ $4.204) \times \mathrm{f}\} \Delta \delta_{\mathrm{eff}}>1$

ただし， $R_{\mathrm{P}}$ : 継手㓮性（面内拘束度） $(\mathrm{kN} / \mathrm{mm} \cdot \mathrm{mm}$ ) $\mathrm{f}$ : 周波数 $(\mathrm{Hz})$

$\Delta \delta_{\text {eff }}$ : 変位方向 (直角, せん断), 開先形状 (突合，すみ肉) などにより補正した值 $(\mathrm{mm})$ 
(1)

継手剛性 $\left(\mathrm{R}_{\mathrm{P}}\right)$ は数值の入力様式のほか, 尃門家以外 が使用する場合には事例に基づいた溶接部の形状と継手 剛性との対照表を作成し,ファクトとして知識ベースに 記述した，ここで, 溶接部の形状は画面の絵から選択す る. $\Delta \delta_{\mathrm{eft}}$ の設定にも継手形状，変位方向との対照表を作 成し,知識ベースにファクトとして記述した。例を表 2 に 示す.

また，4.1 項で選定した溶接捧の $\Delta \delta_{\mathrm{cr}}$ が小さく割れ発 生のおそれがある場合には，拘束材を設置したり交通規 制を寒施して $\Delta \delta$ を低隇するか， $\Delta \delta_{\mathrm{cr}}$ が大きな溶接棒を 使用する必要がある，さらに，既に述べたように，古い 橋梁の鋼材には $\mathrm{P}, \mathrm{S}, \mathrm{C}$ などの高温割れが生じやすい元 素が多く含有されていることも多い. そのため, 初層の みを変動荷重下の耐高温割れ性が優れた専用溶接棒で溶 接したり,バタリングを行うなどの必要があり，事例を ルール化して知識ベースに組み込んだ。

\section{5 知艀ベースの拡張}

振動による欠宿防止には, 現在は実橋において振動を 計測し判定を行っている。しかし, 橋梁の振動は車両の 走行が誘起するため, 部材の固有振動数と強制振動源で ある車両の固有振動数に依存する。したがって，橋梁の タイプ及びサイズと振動の間の相関16)をデータベースと して知識ベースに組み込むことにより，奏測を行わなく ても振動の影響の検討は可能である.

变動荷重下の高温割れ防止にも現地で $\Delta \delta$ 及びその周

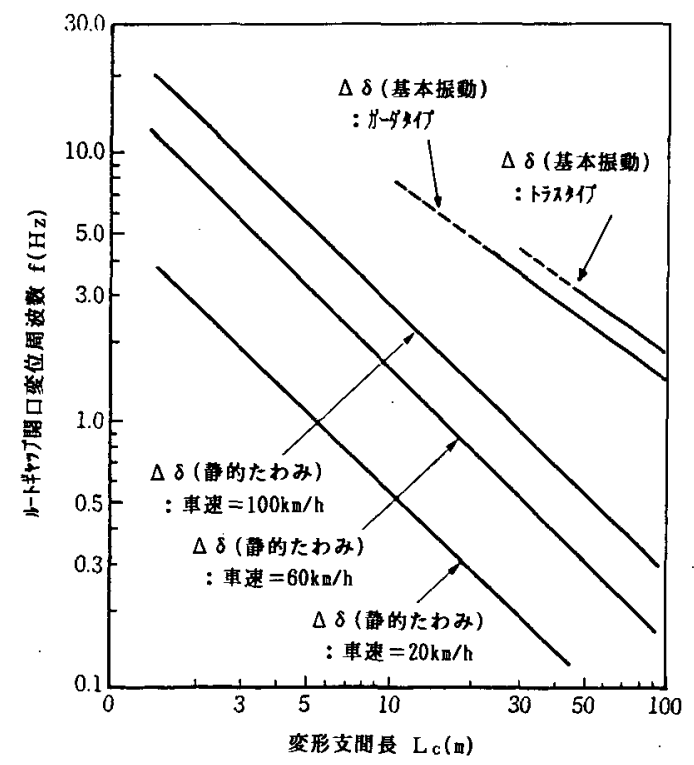

图 6 網橋におけるルートギャップ開口変位周波数 と変形支間長との関係
波数を計測して判定を行っている。一方, $\Delta \delta$ は車両重量 により桁がたわむことにより誘起される成分と走行車両 が誘起する振動の成分が重畳している.そのため, 図6に 例を示すように $\Delta \delta$ の周波数は橋梁の種類, 支間長及び 走行速度に依存する ${ }^{15)}$. また, $\Delta \delta$ の值は車両重量と支間 長, 剛性などに依存する.したがって,これらをデータ ベースとして知識ベースに組み込むことにより，実測を 行わなくても判定が可能となる.

今回開発した知識べースは変動荷重下の溶接を対象と したが, 静的荷重下の溶接, 溶接変形及び温度上昇など を含めたシステムに搪張中であるほか，施工事例のデー タベース化も進めている。 なお, 現地計測を考虑し, 本 システムはバッテリーで使用できるラップトップパソコ ンを用いたポータブル変位計に搭載した.

\section{5. 綱橋の維持管理とデータベース}

胃頭に述べたような理由により，近年国内外て橋梁の 維持管理への関心が高まっている ${ }^{17}$. そのため,橋梁の管 理者は損傷及び補修事例を整理し，データベース化を進 めているが, さらに検査, 損傷の原因解明, 健全性及び 余寿命推定, 補修・補強・改造法の選定と施工法の開発 など多くの研究が行われている17).今回紹介した「交通供 用下溶接エキスパートシステム」はその一部であり, 損 傷の原因解明に関しては, 維持・管理に従事する技術者 に対して情報を提供することを目的とし,「綱橋の疲労損 傷事例のデータベース」が構築されている ${ }^{18}$. さらに, データを広く蓄積し, 健全性, 余寿命推定, 対策の選定 を含めた維持管理システムの開発及び構築も行われてい $3^{19,20)}$.

\section{6. おわりに}

情報データベースの接合・加エプロセスへの応用に関 して，供用下溶接エキスパートシステムにおけるデータ ベースの応用を紹介した．ここで使用したデータベース は，エキスパートシステムに組み込さために既に構築し たデータベースに加工を施したものや新たに構築したも のであり，将来は汎用データベースをエキスパートシス テムで直接活用するためのユーザインターフェースが必 要となると考えられる，とくに，専門家に情報を提供す るのに留まっている事例データベースのエキスパートシ ステムへの組込みが望まれる。

なお，今回は橋梁を対象としてエキスパートシステム とそのデータベースを紹介したが，本システムは綱構造 全体に対して適用可能なものであり，読者諸兄の一助に なれば幸いである。 


\section{参考 文 献}

1）橋梁と基礎（補修と補強特集号)，Vol. 17, No. 8 (1983)

2）新田；建設省中国地方建設局「新観音橋」床板張 替工事, IHI 技報, Vol. 23, No. 8 (1985)

3）井元：補修溶接の採否の決定と施工上のポイント (1) - - 供用下の橋梁- - , 溶接学会誌, Vol. 60, No. $2(1991)$

4）井元，中西，鈴木：供用下溶接エキスパートシス テム(第 1 報 変動荷重下溶接条件選定システ 厶), 土木学会第 46 回年次学術講演会講演概要集 (1991 年, 未刊)

5) 河野, 中西, 井元他; 変動空力載荷中の溶接施工 に関する研究一実構造物の変形挙動と溶接割れ試 験との関連について一, 溶接学会全国大会講演概 要第 37 集 (1985)

6) 鈴木，堀川；応力作用下で溶接された平板に変形 举動, 土木学会論文集 No. $350, \mathrm{I}-2$

7）鈴木，山崎，大澤；既設橋梁の振動下にお汀る現 場溶接施工実験, 土木学会第 37 回年次学術大会講 演概要集, I-96 (1982)

8）井元, 中西, 堀川；変動荷重下の溶接割れに対す る実験的考察，溶接学会論文集，Vol. 7, No. 3 (1989)

9) 井元, 中西, 金, 鈴木, 堀川; 変動荷重下の凝固 割れに対する力学的指標と割れ発生評価式の提 案一供用下にある構造物の溶接施工に関する研究 (第一報)，溶接学会論文集, Vol. 8, No. 1 (1990)
10）井元，金，中西，鈴木，堀川；変動荷重下の凝凝 固割れに対する力学的検討一供用下にある構造物 の溶接施工に関する研究 (第二報), 溶接学会論文 集, Vol. 9, No. 1 (1991)

11）中西, 中村, 佐藤, 西山他; 供用中の補修溶接施 工に関する研究一第 2 報 変動応力下の補修溶接 棒の開発一，IHI 技報，Vol. 27, No. 4 (1987)

12）新田, 井元; 「江淀川橋」工事報告一供用下の溶 接施工法一，IHI 技報，Vol. 31，No. 2 (1991)

13）河野, 中西他；TMCP 綱の溶接割れ感受性に関す る一考察,「TMCP 綱の溶接治金」, 溶接学会溶接 治金研究委員会シンポジウム (1985)

14）伊美, 堀川，鈴木；供用中の橋梁補修における溶 接中の一, 二の検討, 土木学会第 37 回年次学術講 演会講演概要集, I-161 (1983)

15） 井元, 中西, 中村; 供用下にある綱橋の溶接可否 判定法, IHI 技報, Vol. 31, No. 2 (1991)

16）加藤, 島田; 橋梁実測振動特性の統計解析, 土木 学会論文報告集, No. 311 (1981)

17) 三木；橋梁の維持・管理について，道路（19896)

18）三木，坂野，舘石，福岡；綱橋の疲労損傷事例の データベースの構筑とその分野, 土木学会論文報 告集, No. 392/I-9（報告）(1988）

19）稲葉，阿部；国鉄建造物の保守管理標準(綱構造) について(主に疲労に関するもの), 溶接学会溶接 疲労強度研究委員会資料, FS $-727-87$

20）日本綱構造協会; 公共構造物の信頼性評価一構造 物の信頼性評価技術開発特別委員会報告一 (1989) 